\title{
PERTUMBUHAN DAN HASIL HIJAUAN RUMPUT RAJA DAN RUMPUT GAJAH YANG DIPUPUK DENGAN PUPUK ORGANIK KASCING
}

\author{
D. Ariyati, W. Suarna*), dan M. A. P. Duarsa \\ Puslitbang Tumbuhan Pakan Universitas Udayana \\ *) corresponding author : wynsuarna@unud.ac.id
}

\begin{abstract}
ABSTRAK
Percobaan telah dilakukan di Stasiun Penelitian Fakultas Peternakan Universitas Udayana di Jalan Raya Sesetan 122 Denpasar. Percobaan dilaksanakan dengan tujuan untuk mengetahui pengaruh interaksi antara dosis pupuk organik kascing dengan rumput raja dan rumput gajah terhadap pertumbuhan dan produksi hijauan. Percotaan mengunakan rancangan acak lengkap (RAL) pola faktorial. Faktor pertama adalah jenis rumput yaitu rumput raja (Pennisetum purpurhoides = Pennisetum hybrid) dan rumput gajah (Pennisetum purpureum). Faktor kedua adalah dosis kascing terdiri atas tujuh taraf yaitu $\mathrm{ot} \mathrm{ha} \mathrm{t}^{-1,} 5 \mathrm{t} \mathrm{ha}^{-1}, 10 \mathrm{t} \mathrm{ha} \mathrm{a}^{-1,} 15 \mathrm{t}$

$\mathrm{ha}^{-1}, 20 \mathrm{t} \mathrm{ha}^{-1,} 25 \mathrm{t} \mathrm{ha}^{-1}, 30 \mathrm{t} \mathrm{ha} \mathrm{a}^{-1}$. Percobaan menggunakan tiga kali ulangan sehingga terdapat 42 unit percobaan. Variabel yang diamati adalah pertumbuhan tanaman, karakteristik tumbuh, dan hasil hijauan. Hasil penelitian menunjukkan bahwa aplikasi pupuk organik kascing pada rumput gajah dapat meningkatkan pertumbuhan tanaman yang lebih baik dibanding rumput raja, namun rumput raja produksinya lebih tinggi dibanding rumput gajah. Terdapat interaksi antara jenis rumput dengan dosis pupuk terhadap variabel berat kering daun dan warna daun. Dosis optimal kascing berbeda antara rumput raja dengan rumput gajah terhadap produksi hijauan. Dapat disimpulkan bahwa aplikasi pupuk organik kascing $10 \mathrm{t} \mathrm{ha}^{-1}$ pada rumput gajah mampu meningkatkan kepekatan warna daun, sedangkan aplikasi pupuk organik kascing $15 \mathrm{t} \mathrm{ha}^{-1}$ pada rumput raja mampu meningkatkan produksi berat kering daun. Dosis optimal hijauan rumput raja adalah $18,82 \mathrm{t} \mathrm{ha}^{-1}$ dan rumput gajah 17,84 ton masing-masing dengan hasil hijauan $58,66 \mathrm{~g} \mathrm{pot}^{-1}$ dan $61,86 \mathrm{~g} \mathrm{pot}^{-1}$.
\end{abstract}

Kata kunci: rumput raja, rumput gajah, kascing, dosis, hasil hijauan

\section{GROWTH AND FORAGE YIELD OF KING GRASS AND NAPIER GRASS FERTILIZED WITH VERMICOMPOS}

\begin{abstract}
This research has been conducted at Faculty of Animal Husbandry, The University of Udayana research station at Jalan Raya Sesetan 122 Denpasar. The objectives of this experiment were to study the interaction effect of Kascing organic fertilizer dossage with King grass and Napier grass toward its growth and yield. The completly randomized design (CRD) with factorial pattern was applied in this research. The first factor was type of grasses namely king grass (Pennisetum purpurhoides $=$ Pennisetum hybrid) and napier grass (Pennisetum purpureum). The second factor was vermicompos dossages with consist of $\mathrm{o}$ ton/ha, $5 \mathrm{t} \mathrm{ha}{ }^{-1}$, $10 \mathrm{t} \mathrm{ha}^{-1}, 20 \mathrm{t} \mathrm{ha}^{-1}, 25 \mathrm{t} \mathrm{ha}^{-1}$ and $30 \mathrm{t} \mathrm{ha}{ }^{-1}$. Three repetition were applied in this research so that there were 42 units of experiment. Plant growth, growth characteristic, and plant yield were observed as variables. The results showed that application of vermicompos organic fertilizer on elephant grass increased plant growth better than king grass, however king grass had higher yield than elephant grass. There was an interaction between type of grasses with vermicompos fertilizer dossages on leaf dry weight and leaf colour variables. Optimum vermicompos dossage was different between king grass and elephant grass on yield. It can be concluded that application of vermicompos organic fertilizer at $10 \mathrm{t} \mathrm{ha}^{-1}$ on elephant grass could increase the darkness of leaf colour, meanwhile application vermicompos organic fertilizer at $15 \mathrm{t} \mathrm{ha}^{-1}$ on king grass could increase leaf dry weight yield. Optimum dossage of vermicompos fertilizer on king grass yield was $18.82 \mathrm{t} \mathrm{ha}^{-1}$ and on elephant grass was $17.84 \mathrm{t} \mathrm{ha}^{-1}$ with yield of forage were $58.66 \mathrm{~g} \mathrm{pot}^{-1}$ and $61.86 \mathrm{~g} \mathrm{pot}^{-}$ 1 , respectively.
\end{abstract}

Kata kunci: king grass, elephant grass, vermicompos, dosage, yield 


\section{PENDAHULUAN}

Program peningkatan populasi ternak ruminansia selalu dikaitkan dengan peningkatan kualitas dan kuantitas hijauan pakan. Hal ini disebabkan hijauan pakan merupakan makanan utama bagi ternak ruminansia. Penyediaan pakan hijauan yang berkualitas serta tersedia sepanjang tahun merupakan salah satu cara untuk meningkatkan produktivitas ternak ruminansia. Namun usaha tersebut masih mendapat kendala yakni lahan yang biasanya dikembangkan untuk tanaman pakan adalah lahan non produktif seperti misalnya lahan marginal/kering (Suarna et al., 2017). Usaha peningkatan produksi hijauan pakan ternak di daerah padat penduduk semakin sulit sehingga penyediaan hijauan pakan ternak juga berkurang. Kurangnya lahan yang dapat digunakan untuk menanam tanaman hijauan pakan ternak karena bersaing dengan pertanian tanaman pangan.

Salah satu hijauan yang cukup produktif apabila diberikan perlakuan yang baik adalah rumput raja (Pennisetum purpurhoides) dan rumput gajah (Pennisetum purpureum). Rumput ini sangat disukai oleh ternak dan cocok untuk rumput potong (sistem cut and carry) dan sangat memungkinkan untuk dikembangkan pada daerah peternakan dengan lahan hijauan yang semakin sempit. Penanaman dapat dilakukan dengan mudah, baik menggunakan stek, anakan maupun pols atau sobekan rumpun (Suarna et al., 2019). Baik rumput raja maupun rumput Gajah toleransinya terhadap berbagai jenis tanah cukup luas, terutama pada tanah yang berstruktur remah akan memberikan hasil yang sangat memuaskan, serta produksinya akan meningkat dengan meningkatnya kebasahan tanah (Sufiriyanto, 2017). Untuk mempertahankan pertumbuhan tanaman tetap baik ketersediaan hara tanaman mutlak diperlukan. Di daerah marginal sistem intensif yang terdiri dari penggunaan spesies tanaman unggul serta penggunaan pupuk yang dilakukan untuk mengurangi keterbatasan-keterbatasan unsur hara/ defisiensi mineral terhadap pertumbuhan pastura perlu dilakukan (Suarna et al. 2019).

Kascing merupakan salah satu pupuk organik yang mempunyai nilai lebih dibandingkan dengan pupuk organik lain. Pupuk organik kascing merupakan pupuk yang sangat baik karena unsur hara yang dikandung dapat tersedia langsung bagi tanaman. Kascing juga merupakan pupuk organik yang sangat baik intuk meningkatkan aktivitas mikroorganisme dalam tanah. Keuntungan pemanfaatan kascing sebagai pupuk organik disamping mampu memperbaiki sifat-sifat kimia, fisika dan biologis tanah juga membantu mengatasi masalah pencemaran lingkungan. Kascing juga mampu meningkatkan serapan hara N, P, K sehingga sangat baik untuk pertumbuhan naman, disamping itu kascing juga mengandung hormon pertumbuhan auxin (Permana et al., 2015). Memperhatikan potensi kascing sebagai bahan organik diharapkan pemberian kascing dapat meningkatkan ketersediaan air dan nutrien di dalam tanah khususnya pada lahan yang ditanami hijauan pakan ternak sehingga mampu mengatasi, kekurangan hijauan di lahan kering. Melalui peningkatan kadar hara dengan pemupukan kascmg akan dapat meningkatkan produksi dan kualitas rumput sehingga dapat meningkatkan produksi ternak ruminansia dan meningkatkan produktivitas lahan marginal. Di daerah basah dengan irigasi yang baik produksi rumput gajah dapat mencapai $270.000 \mathrm{~kg} / \mathrm{ha}$ (Suarna, 2005), sedangkan rumput raja pada kondisi yang sama produksinya 2 kali lebih tinggi dari rumput gajah (Sajimin dan Purwantari, 2015). Dengan pupuk organik kascing yang memiliki kandungan unsur hara tinggi dan mudah diserap tanaman serta lebih baik dari pupuk anorganik diharapkan pertumbuhan dan hasil hijauannya akan lebih baik.

\section{MATERI DAN METODE}

\section{Materi}

Sebuah percobaan pot telah dilaksanakan di Stasiun Penelitian Fakultas Peternakan Universitas Udayana di Denpasar selama tiga bulan. Bibit tanaman yang digunakan dalam penelitian ini adalah sobekan rumpun "pols" dari rumput raja (Pennisetum purpuroides) dan rumput gajah (Pennisetum purpureum), yang telah dipotong sebagian akar dan daunnya dengan ukuran panjang kurang lebih $20 \mathrm{~cm}$. Bibit diambil dari kebun bibit hijauan pada Peternakan Sapi Potong Siut di desa Tulikup, Gianyar. Pengambilan bibit dilakukan satu hari sebelum penanaman. Tanah jenis Inceptisol yang digunakan diperoleh dari Desa Siut Gianyar. Hasil analisis tanah di Laboratorium Ilmu Tanah Fakultas Pertanian Universitas Udayana menunjukkan bahwa tanah jenis Inceptisol teksturnya terdiri atas: pasir 56,008\%, debu $20,000 \%$, dan liat 23,992\%, tanah tergolong lempung liat berpasir. $\mathrm{pH}$ tanah 7,3 (netral), kadar C organik 1,805\% (rendah), N total $0,105 \%$ (rendah), P tersedia 14,800 ppm (tinggi), $\mathrm{K}$ tersedia 93,000 ppm (rendah), kadar garam 0,14 $\mathrm{mm}$ host/cm (sangat rendah), kadar air kering udara 15,79\%, kadar air pada kapasitas lapang 47,58\%. Polybag yang digunakan berukuran 4 gallon, tinggi $40 \mathrm{~cm}$, dan setiap polybag diisi tanah sebanyak 5 kg. Pupuk organik kascing yang digunakan sesuai dengan perlakuan yakni: o t ha-1, $5 \mathrm{t} \mathrm{ha}^{-1}, 10 \mathrm{t} \mathrm{ha}^{-1}$, $15 \mathrm{t} \mathrm{ha}^{-1}, 20 \mathrm{t} \mathrm{ha}^{-1}, 25 \mathrm{t} \mathrm{ha}^{-1}$, dan $30 \mathrm{t} \mathrm{ha}^{-1}$. 


\section{Metode}

Percobaan menggunakan rancangan acak lengkap (RAL) pola faktorial dengan dua faktor. Faktor pertama adalah jenis rumput yaitu: rumput raja (R1) dan Rumput gajah (R2). Faktor kedua adalah dosis pemupukan kascing yaitu: Ko, K5, K10, K15, K2O, dan K25 dengan dosis pupuk bertutur-turut: o t ha 1, $5 \mathrm{t} \mathrm{ha}^{-1}$, $10 \mathrm{t} \mathrm{ha} \mathrm{h}^{-1}, 15 \mathrm{t} \mathrm{ha}^{-1}, 20 \mathrm{t} \mathrm{ha}^{-1}, 25 \mathrm{t} \mathrm{ha}^{-1}$, dan $30 \mathrm{t} \mathrm{ha}^{-1}$. Percobaan diulang tiga kali sehingga terdapat 42 unit percobaan. Percobaan mengikuti model matematis sebagai berikut:

$$
Y_{i j k}=\mu+\alpha_{i}+\beta_{j}+\alpha \beta_{i j}+\varepsilon_{k(i j)}
$$

Keterangan:

$\mathrm{Y}_{\mathrm{ijk}}=$ variable respons

$\mu=$ Efek rata-rata sebenarnya

$\alpha_{\mathrm{i}}=$ Efek factor tanah

$\beta_{\mathrm{j}}=$ Efek factor kascing

$\alpha \beta_{\mathrm{ij}}=$ Efek interaksi

$\varepsilon_{\mathrm{k}(\mathrm{ji})}=$ galat

Variabel yang diukur meliputi: tinggi tanaman, jumlah daun, luas daun, berat kering, batang, berat kering daun, dan top root ratio. Data yang dipeoleh akan dianalisis dengan sidik ragam dan apabila diantara nilai rata-rata perlakuan menunjukkan perbedaan maka akan dilanjutkan dengan uji Duncan Multiple Range Test (Steel and Torrie, 1989). Takaran kascing optimal pada masing-masing jenis rumput ditetapkan dengan kurva respons berdasarkan hasil hijauan (Mayers, 1971). Model yang digunakan adalah:

Keterangan:

$$
\mathrm{Y}=\mathrm{b}_{\mathrm{O}}+\mathrm{b}_{1} \mathrm{X}+\mathrm{b}_{2} \mathrm{~K}^{2}
$$

$\mathrm{Y}=$ peubah respons

$\mathrm{b}=$ koefisioen regresi

$\mathrm{X}=$ taraf pupuk kascing

\section{HASIL DAN PEMBAHASAN}

Analisis statistik menunjukkan, bahwa pada variabel tinggi tanaman, jumlah daun, jumlah anakan, dan warna daun rumput gajah memberikan pertumbuhan yang nyata lebih tinggi $(\mathrm{P}<001)$ dibandingkan rumput raja. Perbedaan aplikasi berbagai dosis pupuk kascing tidak memberikan pertumbuhan, karakteristika tumbuh, dan hasil hijauan yang berbeda $(\mathrm{P}>0.05)$ pada semua variable penelitian. Interaksi antara jenis rumput dengan aplikasi dosis pupuk kascing menunjukkan perbedaan yang nyata $(\mathrm{P}<0,05)$ pada variabel warna daun dan berat kering daun. Pengaruh jenis rumput dan berbagai dosis pupuk kascing serta interaksinya tidak memberikan hasil berat kering hijauan yang berbeda $(\mathrm{P}>0,05)$, demikian pula terhadap variabel top/root ratio. Sedangkan pada variabel leaf/stem ratio perbedaan yang nyata
$(\mathrm{P}<0,05)$ hanya terjadi karena pengaruh perbedaan jenis rumput. Semua data hasil penelitian disajikan pada Tabel 1.

Hasil analisis statistik menunjukkan, bahwa terhadap keseluruhan variabel yang diamati rumput raja lebih responsif dengan kascing dibanding rumput gajah terhadap variabel produksi tanaman, sedangkan rumput gajah pada pertumbuhannya, ini disebabkan genetik rumput raja lebih baik dibanding rumput gajah sehingga adaptasi pada lingkungan dan produksinya lebih baik. Hasil ini didukung penelitian Sajimin dan Purwantari (2019) dimana produksi rumput raja lebih baik dari rumput gajah, namun rumput gajah menunjukkan pertumbuhan yang lebih baik dibanding rumput raja.

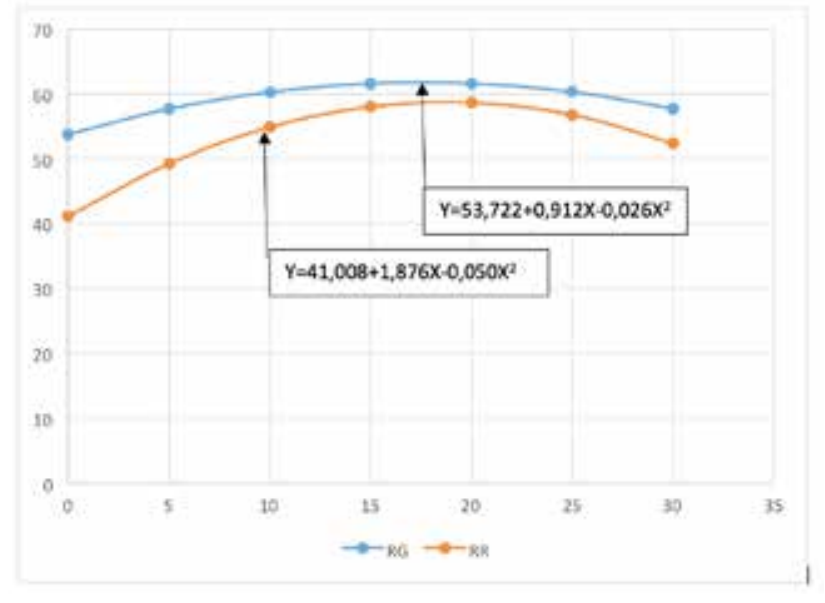

Pemberian berbagai dosis kascing tidak menunjukkan perbedaan yang nyata $(\mathrm{P}>0,05)$ terhadap variabel pertumbuhan dan produksi baik pada rumput raja maupun rumput gajah. Hal ini disebabkan aplikasi kascing sampai $30 \mathrm{t} \mathrm{ha}^{-1}$ belum maksimal memenuhi kebutuhan unsur hara rumput raja dan rumput gajah yang dikenal sangat rakus terhadap pupuk pada tanah inseptisol yang kandungan haranya rendah (Suarna, 2005) dan volume tanah yang minimal sehingga masih perlu ditambahkan. Walaupun berbagai dosis kascing tidak nyata $(\mathrm{P}>0,05)$ berpengaruh pada rumput raja dan rumput gajah, namun pemberian kascing mampu meningkatkan kesiapan tanah inceptiso] untuk ditanami hijauan yang ditunjukkan dengan meningkatnya pertumbuhan dan produksi dibanding kontrol. Pemberian kascing $15 \mathrm{t} \mathrm{ha}^{-1}$ menunjukkan pertumbuhan dan produksi lebih baik dibandingkan dengan yang lain, bahkan terjadi interaksi yang sangat nyata $(\mathrm{P}<0,01)$ antara dosis kascing $15 \mathrm{t} \mathrm{ha}^{-1}$ dengan rumput raja pada variabel berat kering daun. Hasil in membuktikan bahwa kandungan unsur hara dalam kascing dapat dimanfaatkan dengan baik untuk meningkatkan kesuburan dan produktivitas tanah dalam menyediakan unsur hara yang dibutuhkan, namun sampai pada batas tertenu kemudian menurun. 
Tabel 1. Pengaruh Berbagi Dosis Pupuk Kascing dan Jenis Rumput terhadap Pertumbuhan, Karakteristika Tumbuh, dan Hasil Berat Kering Hijauan

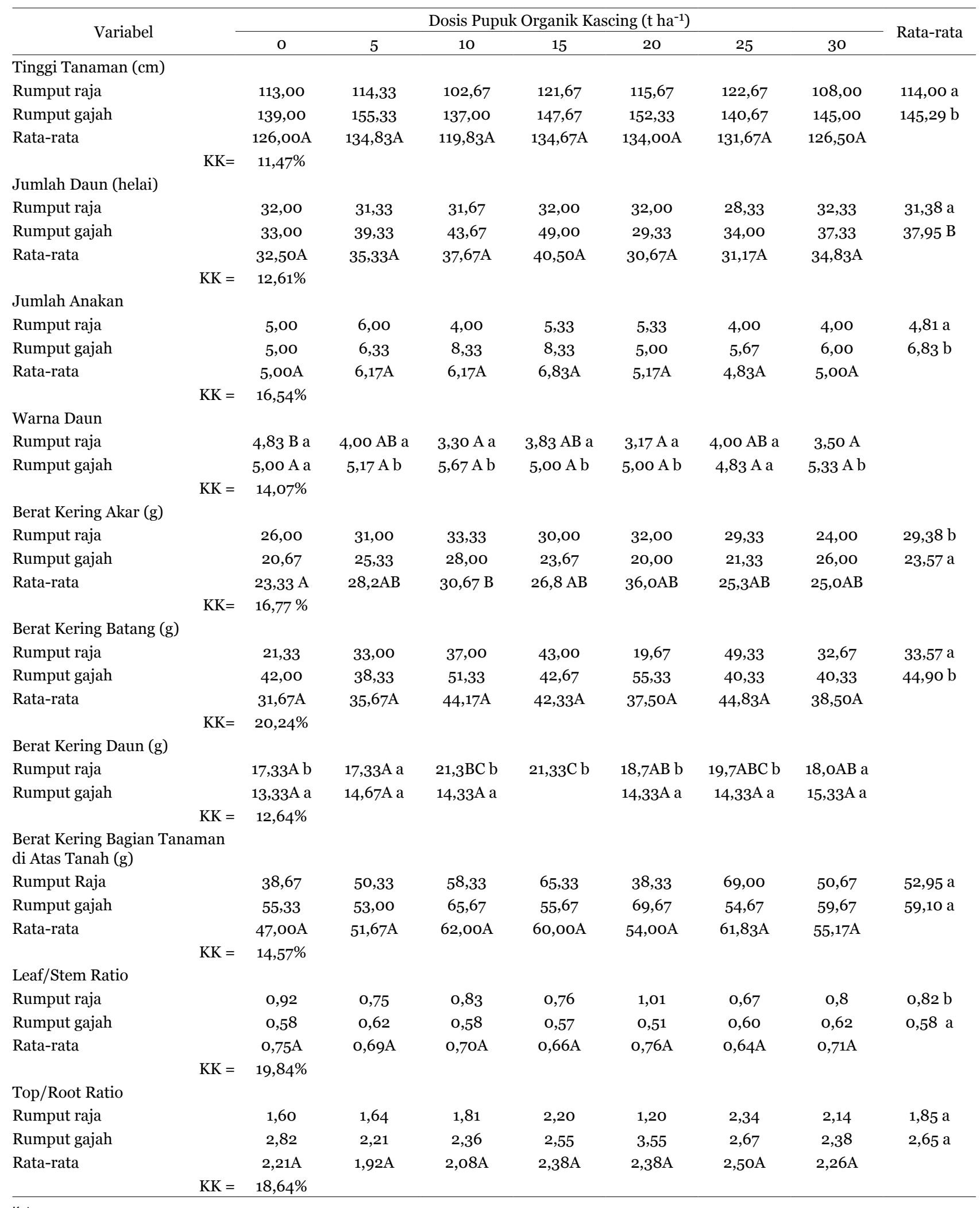

Keterangan:

Angika dengan huruf kapital yang sama pada baris yang sama menunjukkan perbedaan yang tidak nyata $(P>0,05)$, angka dengan huruf kecil yang sama pada kolom yang sama menunjukkan perbedaan yang tidak nyata $(P>0,05)$

Aplikasi kascing $15 \mathrm{t} \mathrm{ha}^{-1}$ memberikan pertumbuhan dan produksi lebih baik dibanding dengan dosis yang lebih tinggi atau lebih rendah dari $15 \mathrm{t} \mathrm{ha}^{-1}$ walaupun tidak berbeda nyata $(\mathrm{P}>0,05)$.
Terdapat interaksi yang sangat nyata $(\mathrm{P}<0,01)$ diantara jenis rumput dengan dosis kascing terhadap variabel berat kering daun dan interaksi yang nyata $(\mathrm{P}<0,05)$ terhadap variabel warna daun, sedangkan 
untuk variabel yang lain tidak berbeda nyata ( $\mathrm{P}>0,05)$. Hal ini disebabkan taraf dosis kascing tidak menunjukkan perbedaan yang nyata $(\mathrm{P}>0,05)$, namun rumput gajah dapat memanfaatkan dengan baik unsur $\mathrm{Ca}, \mathrm{Mg}$ dan $\mathrm{N}$ pada kascing yang sangat berperan dalam meningkatkan kepekatan warna daun dimana pada tanah inseptisol kandungan unsur $\mathrm{N}$ sangat rendah 0,06 \%. Hal ini ditunjukkan dengan aplikasi kascing o ton/ha pada rumput gajah nyata $(\mathrm{P}<0,05)$ meningkatkan kepekatan warna daun dibanding rumput raja. Sesuai dengan pendapat Waluyo et al. (2016) yang menyatakan adanya unsur $\mathrm{N}$ menyebabkan tanaman menjadi lebih hijau daunnya. Tidak berbeda nyata $(\mathrm{P}>0,05)$ untuk dosis yang lebih tinggi atau lebih rendah dari dosis $10 \mathrm{t} \mathrm{ha}^{-1}$ karena kekurangan unsur $\mathrm{N}$ berarti proses fotosintesis terganggu, sedangkan pemberian unsur $\mathrm{N}$ yang lebih tinggi tidak ada lagi pengaruhnya karena tanaman telah tercukupi kebutuhannya sehingga tidak lagi bisa dimanfaatkan.

Pemberian kascing $15 \mathrm{t} \mathrm{ha}^{-1}$ pada rumput raja sangat nyata $(\mathrm{P}<0,01)$ neningkatkan produksi berat kering daun yang lebih tinggi dibanding rumput ajah. Hal ini berarti rumput raja memiliki respon yang lebih baik dengan pemupukan kascing dibanding rumput gajah sehingga dapat memanfaatkan kascing secara maksimal untuk produksi daun. Hasil ini cukup memuaskan karena kascing terbukti mempertinggi kesiapan tanah dalam memacu pertumbuhan daun dengan menyediakan unsur hara yang diperlukan bagi pertumbuhan daun antara lain $\mathrm{Ca}$ dan $\mathrm{Mg}$. Ca dan Mg, menurut Kartini (2018) merupakan unsur hara yang diperlukan untuk pembentukan daun yang tidak disediakan oleh pupuk buatan. Lebih lanjut Suarna et al. (2019) menyatakan $\mathrm{Ca}$ dan $\mathrm{Mg}$ bersama $\mathrm{N}$ perlukan dalam pembentukan klorofil yang dapat meningkatkan kemampuan daun untuk melakukan fotosintesis. Rumput raja kemampuan menyerap nutrisinya lebih baik dibanding rumput gajah dengan dosis optimal $15,89 \mathrm{t} \mathrm{ha}^{-1}$ produksi berat segarnya mencapai 231,80 g pot $^{-1}$, sedangkan rumput gajah dengan dosis optimal 18,09 tha ${ }^{-1}$ produksinya 207,86 g pot $^{-1}$. Namun batang rumput raja lebih sekulen dibanding rumput gajah, sehingga pada dosis optimal produksi berat kering rumput raja menjadi lebih rendah daripada rumput gajah. Hal ini disebabkan oleh pertumbuhan dan produksi yang lebih tinggi menyebabkan semakin banyak individu muda yang terbentuk dimana tanaman yang masih muda kadar airnya tinggi, sehingga kandungan berat keringnya rendah. Walaupun tidak terjadi interaksi yang nyata $(\mathrm{P}>0,05)$ untuk variabel selain warna daun dan produksi berat kering daun namun aplikasi kaseing pada rumput raja dan Gajah mampu meningkatkan pertumbuhan dan produksi tanaman dibanding tanpa pemberian kascing. Tidak terjadi interaksi antara dosis pupuk dengan jenis rumput karena masingmasing faktor berpengaruh sendiri-sendiri terhadap variabel pengamatan. Pada dosis kascing optimal rumput gajah menunjukkan produksi berat kering yang lebih baik dibanding rumput raja.

\section{SIMPULAN}

Aplikasi pupuk organik kascing pada rumput gajah memberikan respons pertumbuhan yang lebih baik daripada rumput raja, tetapi hasil hijauan rumput raja lebih tinggi dari pada rumput gajah. Interaksi terjadi antara jenis rumput dengan pupuk organik kascing terhadap warna daun dan berat kering daun. Penggunaan kascing dengan dosis $10 \mathrm{t} \mathrm{ha}^{-1}$ meningkatkan kepekatan warna daun pada rumput gajah, sedangkan hasil hijauan pada rumput raja meningkat dengan aplikasi kascing $15 \mathrm{t} \mathrm{ha}^{-}$ 1. Ditemukan dosis optimal kascing yang berbeda antara rumput raja dengan rumput gajah terhadap hasil berat kering hijauan. Dosis optimal kasing pada rumput raja adalah $18,82 \mathrm{t} \mathrm{ha}^{-1}$, dan pada rumput gajah adalah $17,84 \mathrm{t} \mathrm{ha}^{-1}$.

\section{DAFTAR PUSTAKA}

Diningtyas, A. S., I. W. Suarna, dan S. A. Lindawati. 2018. Evaluasi Total Bakteri dan Bakteri Pelarut Fosfat pada Rhizosfir Tanaman Stylosanthes guianensis, Gliricidia sepium, Bracharia decumbens, dan Pennisetum purpureum di Lahan Kering pada Musim Hujan. Jurnal Pastura, 8(1): 54-58

Humphreys L. R. 1980. A Guide to Better Pasture for The Tropic and Sub-Tropic. Wright Stephenson \& Co. Pty. Ltd Australia

Kartini, N. L. 2018. Pengaruh Cacing Tanah dan Jenis Media Terhadap Kualitas Pupuk Organik. Jurnal Pastura, 8(1): 49-53

Kartini, Ni Luh. 1997. Efek Inokulasi Mikonza Vesikuler-Arbuskular (MVA) dan Aplikasi Pupuk Organik Kascing terhadap P-Tersedia Tanah, Konsentrasi P Tanaman dan Hasil Bawang Putih (Allium satuvum L.) pada Inceptisol. Disertasi Pasca Sarjana. Universitas Padjadjaran. Bandung. Myers, R. H. 1971. Response Surface Methodology. Allyn and Bacon, Inc. Boston

Permana, A.T., L. Abdullah, P.D.M. Karti, T. Toharmat, Suwarno. 2015. Efektivitas Vermikompos Eisenia foetida Savigny dalam Memperbaiki Tingkat Produksi dan Kualitas Nutrisi Sorghum bicolor (L.) Moench dan Centrosema pubescens Benth. Jurnal Pastura, 5(1): 7-9.

Sajimin and N. D. Purwantari. 2019. Evaluation 
Performance of Three Pennisetum Genus Grown on Pines Forest in Lembang, West Java. Jurnal Pastura, 8(2): 97-100

Steel, R. G. dan J. H. Torrie. 1989. Principles and Procedure of Statistics. Mc Graw Hill Book Company, New York.

Suarna, I W. 2005. Peningkatan produktivitas rumput raja melalui aplikasi teknologi budidaya yang ramah lingkungan. Jurnal Bumi Lestari, 5 (1): 23-27).

Suarna, I W., I K.M Budiasa, T. I. Putri, N. P. Mariani, dan M. Hartawan. 2017. Potensi Bio-Slurry dalam Peningkatan Karakteristik Tumbuh dan Produksi Pastura Campuran pada Lahan Kering di Desa Sebudi Karangasem Jurnal Pastura, 6(2): 70-73

Suarna, I W., N. N. Candraasih K., dan M.A.P. Duarsa. 2014. Model Asosiasi Tanaman Pakan Adaptif untuk Perbaikan Lahan Pasca Tambang di Kabupaten Karangasem. Jurnal Bumi Lestari, 14 (1): 9-14

Suarna, I W., N.N. Suryani, dan K.M. Budiasa. 2019. Biodiversitas Tumbuhan Pakan Ternak. Prasasti, Denpasar, Bali.

Sufiriyanto, S. Hastuti dan E. Yuwono. 2017. Efektivitas Pupuk Organik Cair "Usb" dan Suplementasi Herbal terhadap Produktivitas Rumput Gajah. Jurnal Pastura, 6(2): 53-58

Waluyo, W. W. S., S. Suharti, dan L. Abdullah. 2016. Metode Cepat Pendugaan Kandungan Protein Kasar pada Rumput Raja (Pennisetum urpurhoides) Menggunakan Nilai Indeks Warna Daun Jurnal Pastura, 5(2):78-82 